\title{
O Sagrado e o Profano na Urbanidade: Borges - Análise do poema "Carnicería"
}

\section{El sagrado y el profano en la urbanidad: Borges - Análisis del poema "Carnicería"}

\author{
Victor DE Lima TORQUATO DE ANDRADE
}

\section{RESUMO}

Este ensaio lança luz ao desdobramento dialético do sagrado e do profano contidos no poema "Carnicería", já que a análise de tal binômio é capaz de evidenciar a forma como Borges rompe com tradições acerca de imagens comuns da urbanidade: sejam elas uma rua, um açougue ou uma casa de prostituição. E é justamente no momento em que colocamos a lupa científica sobre esta quebra de tradições que vemos surgir o sangue vanguardista do poeta: vemos o transmutar de conteúdos semânticos, as surpresas advindas das articulações entre o antigo e o novo, e uma singular redefinição estética. Ademais, a presente análise procurou respeitar a dinâmica do olhar: cada verso foi analisado na própria sequência do poema, assim, mantendo-se fiel à sucessão de imagens que o poeta construiu, buscando mimetizar o gesto de ler o poema, e de se pensar enquanto se lê.

PALAVRAS-CHAVE: Borges; análise poética; sagrado e profano; vanguarda latino-americana.

\section{RESUMEN}

Este ensayo busca revelar el desdoblamiento dialéctico del sagrado y del profano contenidos en el poema "Carnicería". Ya que el análisis de este binomio tiene la capacidad de evidenciar la forma como Borges rompe con tradiciones y imagines comunes de la urbanidad: sean una calle, una carnicería o una casa de prostitución. Y es justamente en el momento en que colocamos la lupa científica sobre esta ruptura de tradiciones que vemos surgir la sangre vanguardista del poeta: vemos la transmutación de los contenidos semánticos, las sorpresas originadas de las articulaciones entre el antiguo y el nuevo, y una singular redefinición estética. Además, el presente análisis procuró respectar la dinámica de la mirada: cada verso fue analizado en su propia secuencia en el poema, así, manteniéndose fiel a la sucesión de imágenes que el poeta construyó, buscando mimetizar el movimiento de leer el poema y de pensar mientras se lo lee.

PALABRAS CLAVE: Borges; análisis poético; sagrado y profano; vanguardia latinoamericana. 


\author{
Carnicería \\ Jorge Luís Borges \\ Más vil que un lupanar \\ la carnicería rubrica como una afrenta la calle. \\ Sobre el dintel \\ una ciega cabeza de vaca \\ preside el aquelarre \\ de carne charra y mármoles finales \\ con la remota majestad de un ídolo${ }^{1}$.
}

\title{
Carnicería - o SAGRAdo E O PROFANO Na URBANIDADE
}

A análise (ou melhor: dissecação. Certamente o meu trabalho será análogo ao labor de alguém que corta a carne e expõe a medula) poderia começar de muitas formas, entretanto, depois de muito encarar a cabeça muda de uma vaca, decido aqui iniciar com um aforismo que poderia muito bem ser a epígrafe do açougue poético criado por Borges - da mesma maneira que a cabeça bovina é a epígrafe da modernidade²: "Um monge e um açougueiro brigam no interior de cada desejo" (CIORAN, 2011, p. 83).

O que há no símbolo do "monge" e do "açougueiro" que os fazem de extrema valia para o presente ensaio? Tudo. O monge é um referencial de ascetismo, de placidez, de eternidade, e de imobilidade; enquanto que o açougueiro é um referencial de hedonismo, de voracidade, de efemeridade, e de agitação. A tensão entre esses dois grupos semânticos atravessa a poesia inteira do mesmo jeito que o espeto atravessa a carne do desejo quando estamos diante do churrasco.

A primeira parte da poesia ("Mais vil que um lupanar") já nos coloca de frente a um conflito que, num primeiro momento, não é tão evidente; mas, ao descascarmos a superfície do verso, podemos vislumbrar o coração pulsante que ali reside: Borges não usa o vocábulo "prostíbulo" (de igual grafia em espanhol) ou "bordel" (burdel em espanhol) no lugar de "lupanar" (por mais que essas palavras sejam muito mais frequentes - tanto na língua espanhola, quanto na língua portuguesa - para apontar uma casa de prostituição), e assim, faz questão de que o açougue seja mais vil que um lupanar, e não mais vil que um bordel ou um prostíbulo. Ora, o que há no lupanar que não há na palavra "prostíbulo" e "bordel"? De

\footnotetext{
1 Transcrito a partir da seguinte edição: BORGES, Jorge Luís. Obras completas. Buenos Aires: Emecé, 1984. p. 31.

2 Sempre que a palavra "modernidade" ou "moderno" for utilizada neste textonão será em alusão ao movimento modernista e a nenhuma característica dele, mas, sim, à condição social e filosófica de homem moderno do século XX.
} 
certo, a origem e a marcação de temporalidade. A palavra "lupanar" remonta-nos ao tempo Greco-romano, tempo em que as casas de prostituição possuíam exatamente esse nome ("lupanar"); então, quando o poeta diz que o açougue - que encabeça o título - é mais vil que um lupanar, está intrinsecamente falando que o açougue "é mais vil que aquilo que há de mais vil na antiguidade”, ou seja, está redefinindo uma estética da antiguidade sob o signo do açougue! E redefinição estética é justamente uma das marcas vanguardistas latinoamericanas, além do mais, ao tensionar a antiguidade de um lupanar com a modernidade de um açougue, o poeta potencializa a impureza do estabelecimento, faz com que o ímpio borbulhe com ainda mais intensidade; intensidade que já está presente no nome da obra em que esta poesia se encontra: Fervor de Buenos Aires.

"Mais vil do que aquilo que há de mais vil" nos primórdios da civilização ocidental, $o$ açougue rubrica como uma afronta a rua. - Aqui aparece um tema constante na arte poética vanguardista: a urbanidade (sob a égide da palavra "rua”). E em Borges, amiúde, o centro urbano não se revela como um símbolo de comemoração, porém, sim, como um elemento que deve ser confrontado, assim como a presença do açougue confronta a rua. Para ressaltar essa característica borgiana, vale a pena trazer à tona a seguinte citação de Júlio Pimentel Pinto:

\footnotetext{
No caso específico de Borges, mais longamente analisado, a história tem na cidade uma espécie de palco onde se apresentam seus dilemas. É lá que as temporalidades dialogam e ocasionalmente se opõem, é lá que se criam mecanismos de lidar com a mudança, mesmo quando ela é diferentemente percebida. E é nessas mesmas ruas, destaca Borges, que nos achamos, ao contrário da celebração "modernolátrica" que reconhece nelas um lugar de perda. (PINTO, 2002)
}

Ou seja, na presente poesia nos achamos numa rua que é provocada por um açougue, não nos perdemos na rua, nos perdemos na contemplação rubra do açougue; inclusive, a ação de rubricar é constituída de dois sentidos: é uma assinatura e também é uma cor que não podem passar indiferentes a um observador, é uma palavra e uma sensação, é o ato de se estranhar na leitura e o ato de se estranhar no sentir. E o que significa essa estranha capacidade que o açougue possui de afrontar a rua? A rua, as esquinas, o centro urbano, as encruzilhadas da metrópole são imagens marcantes da velocidade e agitação moderna; são símbolos de pessoas que passam e não se percebem, dos olhares que se cruzam e que não permanecem; e se a rua traz toda essa gama de significados, e se todos esses significados são colocados em conflito com a imagem do açougue, então há no açougue algo que detenha o olhar, que seja capaz de frear o nosso ímpeto veloz, e que tenha o poder de nos permitir um momento de reflexão e contemplação - conferir essas características a um açougue é algo extremamente singular e transgressor, pois geralmente este estabelecimento de carnificina é associado justamente às características opostas; logo, é como se nesta poesia o açougue fosse um lugar de encontro entre o monge e o açougueiro, entre o sagrado/contemplativo e o profano/aversivo.

$\mathrm{O}$ terceiro e quarto versos trazem duas imagens que novamente assinalam a ruptura e a 
passagem entre o mundo antigo e o mundo novo: primeiro o poeta nos localiza espacialmente com o verso "Sobre o dintel" - a expressão sobre é de extrema importância e relevância, pois nos leva ao pensamento de superação, de ultrapassagem ou de apoio daquilo que o dintel significa. A rigor, dintel é uma estrutura arquitetônica composta de duas colunas que suportam uma base superior, contudo, dentro desta poesia, é possível inferir que seja muito mais do que isso: o dintel é uma marca clássica da arquitetura Greco-romana, encontrando-se tal estrutura em casas, templos, arenas etc. (somos passíveis de averiguar esse fato ainda hoje nas construções Greco-romanas que foram preservadas ao longo do tempo). E já que esta poesia logo no primeiro verso nos introduz a um conflito entre o antigo e o novo, temos jurisprudência para dizer que "Sobre o dintel" admite a seguinte leitura: "superando a antiguidade clássica, calcado na antiguidade clássica" está uma cega cabeça de vaca; como se a cabeça de vaca ao mesmo tempo superasse o antigo e estivesse apoiada em algo do antigo; como se a cabeça de vaca fosse um busto da modernidade sobre o material da antiguidade - o intercâmbio de características é mais uma vez notável: o busto não é de mármore, pedra ou bronze, mas é de carne; e sendo de carne, carrega em si os traços da decomposição e efemeridade, porém, sendo de uma carne morta, também traz consigo um aspecto de eternidade e imobilidade, pois a morte é para sempre, é um repouso ininterrupto.

Além disso - ainda acerca do terceiro e quarto versos —, não se pode deixar passar a ênfase no olhar da vaca: um olhar cego. Se todo esse processo poético se dá numa voltagem entre a rua e o açougue, entre um observador e uma cabeça de vaca, também existe a tensão do olhar: entre algo que vê da perspectiva da rua e de uma cabeça que não enxerga da perspectiva do açougue; entre um voyeur implícito (afinal, nenhum sujeito é descrito na poesia, entretanto intuímos que a rua, por ser local de agitação, é composta de sujeitos observadores) e um antivoyeur explícito (a cabeça do bovino está ali, cega, descrita de forma clara e direta) — a "poética do olhar" é constante nas temáticas vanguardistas latino-americanas, sendo que, muitas vezes, podemos encontrar um sujeito voyeur que caminha pela cidade e, no ato de caminhar, suscita no olhar o questionamento acerca da condição de homem moderno. Nesta poesia não há um sujeito que caminha, mas há uma rua que observa um açougue, uma rua sob a condição de voyeur. Uma rua que, no ato de observar e de ser confrontada, suscita no leitor uma aprofundada reflexão sobre os traços da modernidade e suas confluências e fraturas com a antiguidade.

Os três últimos versos surgem para qualificar a cabeça de vaca como se colocassem uma coroa sobre ela; - e a palavra "coroa" não é um exagero de linguagem, pois a cabeça do bovino é relacionada com a majestosa figura de um ídolo. Todavia, antes de começar a autopsia do último verso (“com a remota majestade de um ídolo"), faz-se necessário compreender como chegamos nele, faz-se necessário investigar a luz que o quinto e o sexto verso ("preside a algazarra" e "de carne charra e mármores finais") lançam sobre o sétimo verso. 
O quinto e o sexto verso lustram - e reiteram - as contradições que estão contidas na imagem da cabeça de vaca: é a figura decapitada deste bovino que sintetiza o grotesco da carne e o plácido do mármore; o hedonismo do açougueiro e o ascetismo do monge; se por um lado a cabeça traz a efervescência da rua e dos centros urbanos através da visão da carne, da vida que se deforma, por outro lado também traz a distância que é própria dos artefatos sacros, da morte que sela algum mistério e que é capaz de seduzir qualquer observador que se encontra diante de um túmulo, de um mármore final. Desta forma, a cabeça de vaca tem tudo que é necessário para receber a adjetivação (e como dito anteriormente: coroa) que se dá no último verso: o signo bovino preside todos esses conflitos e tensões com a remota majestade de um ídolo - duas coisas são necessárias para que algo se transforme num ídolo: proximidade com os que veneram, e ao mesmo tempo, distância; é necessário proximidade para que as pessoas se reconheçam no objeto de veneração, e concomitantemente, é necessário distância para que as pessoas possam perceber que algo do objeto está além delas, que algo do objeto reside num plano metafísico que supera a condição material ao qual estão presas (é por isso que a expressão “majestoso ídolo" vem acompanhada da palavra "remota”, pois é tal palavra que adiciona o caráter de longínquo ao ídolo; tanto no sentido temporal quanto no sentido de que há algo além do plano físico); basta pensarmos no ídolo mais pétreo que a humanidade ocidental já concebeu: Jesus Cristo; ao mesmo tempo em que Jesus é carnal, também é espiritual; ao mesmo tempo em que está próximo dos homens por ser homem, também está distante por ser Deus. O “ídolo cabeça de vaca” está próximo pela carne da vida, e distante pelo mármore da morte.

"Carnicería" mexe e transmuta as concepções tradicionais que possuímos acerca de determinadas imagens (fazendo jus ao vanguardismo em que se insere): o açougue não carrega apenas o vetor de caos e carnificina, mas aqui também é objeto de contemplação e solenidade; a cabeça de uma vaca não é apenas um elemento de aversão e decomposição, mas aqui também é elemento de veneração e sacralidade. A rua não é observada por algo, mas é observadora de algo. É como se esta poesia de Borges tivesse sido pintada por Picasso: ao olharmos para ela, somos introduzidos a um universo de sobreposição de significados, a um universo em que os significados opostos se somam e não se subtraem. Ler "Carnicería" é ser colocado diante de um açougue que também é templo, de um cadáver que também é ídolo, e de uma poesia que também é pintura.

\section{Referências bibliográficas}

BORGES, J. L. “Carnicería”. In: Obras completas. Buenos Aires: Emecé, 1984. p. 31.

BORGES, J. L. “Açougue”. In: MATTOSO, G.; SCHWARTZ, J. (tradução). Obras completas. São Paulo: Globo, 1999.

CIORAN, E.M. Silogismos da Amargura. Rio de Janeiro: Rocco, 2011. 
PINTO, Julio Pimentel. Ruas de Borges e de seus contemporâneos In: História (São Paulo), v. 22-2, p. 121-132, 2003. 